Pawet Czechowski, Adam Niewiadomski

\title{
Tendencje rozwoju polskiego prawa rolnego w związku z uzyskaniem członkostwa Polski w Unii Europejskiej
}

\section{Oddziaływanie prawodawstwa Unii Europejskiej na polskie prawo rolne}

Wejście Polski do Unii Europejskiej wraz z dziewięcioma innymi państwami 1 maja 2004 roku spowodowało istotne zmiany w zakresie prawa we wszystkich jego aspektach. Poczynając od powstania nowych źródeł prawa, poprzez instytucje prawne, po nowe zasady stosowania prawa, dające generalnie pierwszeństwo rozporządzeniom europejskim przed polskimi ustawami. Pięć lat temu nastąpiło zderzenie dwóch porządków prawnych: polskiego i europejskiego ${ }^{1}$. Proces ten był najbardziej widoczny w sferze regulacji prawa rolnego i żywnościowego. Regulacje Unii Europejskiej, stanowiące w omawianej dziedzinie ponad 50\% całości stanowionego prawa, napotkały na trudności implementacyjne oraz dostosowawcze. Problemy te pogłębiały się, gdy spojrzymy na proces stosowania prawa, w szczególności przez organy władzy oraz administracji publicznej, które stanęły po uzyskaniu członkostwa przed wyzwaniem harmonizacji prawa polskiego z prawem Unii Europejskiej, także $w$ aspekcie potrzeby rozdziału ogromnych środków finansowych przeznaczanych na pomoc dla rolnictwa.

Na długo jeszcze przed 1 maja 2004 r. prawodawca polski rozpoczął tzw. proces ,dostosowywania” prawa polskiego do regulacji obowiązujących we Wspólnocie Europejskiej. Proces ten polegał na zbliżaniu rozwiązań obu systemów prawnych. Rozwiązania polskie dostosowywane były do wzorów rozwiązań europejskich. W 1994 r. powołano w celu usprawnienia tego procesu m.in. Zespół Ekspertów ds. Harmonizacji Prawa Polskiego z Prawem Wspólnot Europejskich, działający przy Biurze Pełnomocnika Rządu do spraw Integracji Europejskiej i Pomocy Zagranicznej, a następnie przy Urzędzie Komitetu Integracji Europejskiej, który określił tryb

P. Czechowski, Proces dostosowywania polskiego prawa rolnego i żywnościowego do prawa Unii Europejskiej, Warszawa 2001, s. 7; A. Jurcewicz, B. Kozłowska, E. Tomkiewicz, Wspólna Polityka Rolna. Zagadnienia prawne, Warszawa 2004, s. 50 i nast.; por. także R. Budzinowski, Czynniki rozwoju prawa rolnego w Polsce, (w:) Polskie prawo rolne u progu Unii Europejskiej, S. Prutis (red.), Białystok 1998, s. 37-38. 
i zasady dostosowania prawa ${ }^{2}$. Proces implementacji przerodził się szybko w proces harmonizacji prowadzony przez poszczególne ministerstwa. Podczas tego procesu, obok regulacji materialnoprawnych i formalnoprawnych, zapisywano w aktach prawnych różnej rangi, że wchodzą one w życie wraz z wejściem Polski do Unii Europejskiej lub 1 maja 2004 r. Takie rozwiązanie wymagało przygotowania setek aktów prawnych, które z dniem wejścia Polski do Unii Europejskiej miałyby stać się obowiązującym prawem. Nie możemy zapominać, że obok nowego prawodawstwa polskiego implementującego rozwiązania wspólnotowe, z dniem 1 maja 2004 r. w prawodawstwie polskim pojawiło się kilkadziesiąt tysięcy bezpośrednio stosowanych aktów prawnych Unii Europejskiej. Wszystkie unijne akty normatywne musiały zostać uprzednio przetłumaczone, a tam, gdzie wymagano wydania aktów wykonawczych przez państwo członkowskie, należało takie akty uchwalić. Dostosowanie porządku prawnego do prawa Unii Europejskiej było ,,jednostronnym zespołem czynności prawnych i faktycznych, które obejmują wszystkie reguły należące do acquis communautaire jako ostatecznego celu związanego z zapewnieniem zdolności do korzystania ze statusu Unii Europejskiej."”. Cel ten starano się zapewnić w możliwie szybkim czasie. Przypomnieć należy, że Dziennik Ustaw z okresu bezpośrednio uprzedzającego przystąpienie Polski do Unii Europejskiej zajmuje objętość odpowiadającą kilku rocznikom, biorąc za porównanie prawodawstwo okresu poprzedniego.

W okresie 2000-2004 podjęto szereg działań dostosowawczych w zakresie prawa rolnego ${ }^{4}$. Można tu wymienić chociażby powołanie instytucji wspomagających regulację rynku rolnego poprzez przekształcenie rolnych agencji interwencyjnych w agencje interwencyjne i płatnicze według zasad prawa europejskiego. Dostosowano w tym zakresie odpowiednio regulacje dotyczące Agencji Rynku Rolnego oraz Agencji Restrukturyzacji i Modernizacji Rolnictwa, przygotowując je do pełnienia zadań w zakresie płatności różnego rodzaju środków pomocowych dla polskiego rolnictwa. Zadbano o przygotowanie właściwych procedur i podstaw prawnofinan-

Por. Zarządzenie Pełnomocnika Rządu ds. Integracji Europejskiej z 24 lutego 1994 r. oraz Zarządzenie nr 5 Sekretarza Komitetu Integracji Europejskiej z 17 marca 1997 r.; por. P. Czechowski, Harmonizacja prawa polskiego ze standardami europejskimi. Założenia programu, (w:) „Nowe Życie Gospodarcze” 1996, nr 25, s. 50-53; W. Cimoszewicz, Harmonizacja prawa polskiego ze standardami europejskimi, (w:) Kwartalnik Prawno-Ekonomiczny 1996,nr 1, s. 7-9.

3 C. Mik, Europejskie prawo wspólnotowe. Zagadnienia teorii i praktyki, Warszawa 2000, s. 794; A. Wasilkowski, Zbliżenie prawa w procesie integracji europejskiej, Warszawa 1995, s. 5 i nast.; J. Jaskiernia, Badanie zgodności projektów ustaw z prawem Unii Europejskiej w sejmowym postępowaniu ustawodawczym, „Państwo i Prawo” 200 ,z. 7, s. 32; P. Czechowski, Prawne aspekty procesu integracyjnego polskiego rolnictwa ze Wspólnotą Europejska, (w:) Prawo rolne. Biała księga. Polska, Unia Europejska, opracowania i analizy, Seria „Prawo”, Warszawa 1994, s. 19-45.

4 P. Czechowski, Dostosowanie polskiego prawa rolnego i żywnościowego do prawa wspólnotowego po akcesji do Unii Europejskiej. Suplement do publikacji Proces dostosowywania polskiego prawa rolnego i żywnościowego do prawa Unii Europejskiej, Warszawa 2005, s. 60 i nast. Wskazać również należy na istotny czynnik globalizacji regulacji prawnych w rolnictwie związany z Rundą Urugwajską GATT, w tym z Traktatem z Marrakeszu (1995 r.) w sferze liberalizacji handlu, por. przykładowo R. Budzinowski, Międzynarodowe czynniki rozwoju prawa rolnego, „Przegląd Prawa Rolnego” 2007, nr 2, s. 31 i nast. 
sowych w celu wykorzystania subwencji i dofinansowań pochodzących z funduszy strukturalnych, takich jak np. Europejski Fundusz Orientacji i Gwarancji Rolnej. Nowością stały się obligatoryjne rolnicze badania rynkowe, które miały usprawnić procesy produkcyjne ${ }^{5}$. Zaczęto organizować grupy producenckie ${ }^{6} \mathrm{w}$ celu efektywniejszego gospodarowania, racjonalizacji produkcji, wzajemnego wsparcia, a przede wszystkim w celu sprostania konkurencji na wspólnym rynku europejskim.

Jednym z poważniejszych i trudniejszych do wykonania zadań stało się administrowanie eksportem i importem produktów rolnych. Dotyczyło to wydawania licencji eksportowych oraz importowych organizujących obrót towarowy z zagranicą, sposobu wydawania właściwych świadectw inspekcji handlowych i sanitarno-weterynaryjnych, regulowania dopłat eksportowych. Po wstapieniu Polski do Unii Europejskiej większość tej problematyki jest regulowana obecnie prawem wspólnotowym.

Nowego kształtu w procesie dostosowywania prawa nabrały unormowania dotyczące domów składowych oraz giełd towarowych ${ }^{7}$. Budowane są od podstaw prawno-organizacyjne struktury branżowych rynków rolnych ${ }^{8}$ oraz procedury standaryzacji i certyfikacji produktów rolnych. Proces ten obejmuje swym zakresem przede wszystkim kontrolę i utrzymywanie jakości handlowej artykułów rolno-spożywczych $^{9}$, wprowadzenie standaryzowanych norm dla tych produktów ${ }^{10}$, rozwój działu produkcji ekologicznej ${ }^{11}$. Nowe uregulowania dotyczą także ochrony nazw geogra-

Problematykę tę szczegółowo uregulowano w ustawie z 30 marca 2001 r. o rolniczych badaniach rynkowych (Dz.U. Nr 42, poz. 471 z późn. zm.). W myśl tej ustawy rolnicze badania rynkowe polegają na zbieraniu i opracowywaniu informacji o poziomie cen i wielkości obrotu artykułami rolno-spożywczymi. Ustawa zawiera także szereg definicji, porządkujących regulowany zakres. Jedną z nich jest definicja danych rynkowych rozumianych jako informacje o poziomie cen i wielkości obrotu artykułami rolno-spożywczymi, niezależnie od miejsca jego prowadzenia, związanych z przedsiębiorca. Rolnicze badania prowadzone są przez ministra właściwego do spraw rynków rolnych i polegają na opracowaniu metodologii rolniczych badań rynkowych, zbieraniu danych rynkowych, tworzeniu i zarządzaniu elektroniczną bazą danych, obejmująca dane rynkowe oraz ich zabezpieczaniu, przetwarzaniu oraz analizie danych rynkowych, udostępnianiu i rozpowszechnianiu wyników rolniczych badań rynkowych, szkoleniu w zakresie rolniczych badań rynkowych itp.

6 P. Czechowski, Organizacja grup producentów rolnych w świetle ustawodawstwa Unii Europejskiej, „Podatki i Prawo Gospodarcze Unii Europejskiej" 1999,nr 1, s. 18-20.

7 Por. ustawę $z$ dnia 16 listopada 2000 r. o domach składowych oraz o zmianie kodeksu cywilnego, kodeksu postępowania cywilnego i innych ustaw (Dz.U. Nr 114, poz. 1307) oraz ustawę z dnia 26 października 2000 r. o giełdach towarowych (Dz.U. Nr 103, poz. 1099); por. B. Jeżyńska, Instytucje rynku towarów giełdowych, (w:) Prawo rolne, A. Stelmachowski (red.), Warszawa 2006, s. 412.

8 Obejmuja one m.in. rynek: cukru, owoców i warzyw, chmielu i produktów chmielu, tytoniu, suszu paszowego, mleka i przetworów mlecznych, skrobi ziemniaczanej, przetworów owocowo-warzywnych, zbóż, roślin oleistych, Inu uprawnego, roślin strączkowych, Inu i konopi, oliwy. Nowe regulacje UE dotyczące rynków rolnych zostały zawarte w rozporządzeniu Rady (WE) nr 1234/2007 z dnia 22 października 2007 r. ustanawiającym wspólną organizację rynków rolnych oraz przepisy szczegółowe dotyczące niektórych produktów rolnych (rozporządzenie o jednolitej wspólnej organizacji rynku) (Dz.Urz. L 299 z 16.11.2007, s. 1-149).

Ustawa z dnia 21 grudnia 2000 r. o jakości handlowej artykułów rolno-spożywczych (Dz.U. Nr 5, poz. 44); por. M. Korzycka-Iwanow: Prawo żywnościowe. Zarys prawa polskiego i wspólnotowego, Warszawa 2005, wyd. II 2007 i tamże zebrana literatura; P. Wojciechowski, Wspólnotowy model urzędowej kontroli żywności, Warszawa 2008.

10 Ustawa z dnia 3 kwietnia 1993 r. o normalizacji (Dz.U. Nr 55, poz. 251 z późn. zm.).

11 Ustawa z dnia 16 marca 2001 r. o rolnictwie ekologicznym (Dz.U. Nr 38, poz. 452); por. E. Jaska, Szanse polskiego rolnictwa w produkcji ekologicznej, (w:) Problemy integracji rolnictwa polskiego z Unią Europejską, A. Kwieciński, H. Runowski, J. Wilkin (red.), Warszawa 1994; U. Sołtysiak, O kryteriach w rolnictwie ekologicznym, (w:) 
ficznego pochodzenia i certyfikacji produktów specjalnego pochodzenia ${ }^{12}$. Rozpoczęto także prace nad szeregiem regulacji dotyczących produkcji rolnej i żywności modyfikowanej genetycznie ${ }^{13}$.

Osobnym działem, w którym zintensyfikowano działania przygotowujące do wprowadzenia odpowiedniego ustawodawstwa, był sektor regulacji dotyczący rolnictwa w sferze strukturalnej. Przede wszystkim zintegrowano system zarządzania i kontroli ${ }^{14}$ oraz przygotowano się do wprowadzenia sytemu rent strukturalnych ${ }^{15}$. Osobną problematyką było wspomaganie rozwoju gospodarstw rolnych oraz infrastruktury w regionach górskich i pogórskich, którą uregulowano w ustawie z dnia 26 lipca 2001 r. o rozwoju społeczno-gospodarczym regionów górskich. Najbardziej emocjonującą kwestią stała się regulacja obrotu ziemią, a w szczególności nabywania jej przez cudzoziemców w świetle zasady swobody przepływu kapitału. Ofensywna kampania polityczna przyczyniła się do nowelizacji ustawy z $1920 \mathrm{r}$. o nabywaniu nieruchomości przez cudzoziemców. Wprowadzenie okresów przejściowych było odczytywane przez niektóre kręgi opiniotwórcze jako niechęć do integracji i zmian. Kwestia o znaczeniu marginalnym - jak się później okazało - dla gospodarki państwa, stała się w okresie przedakcesyjnym dominującą sprawą polityczną i prawną, wywołującą szereg emocji. Procesy powyższe odnotowano również w innych krajach kandydujących ${ }^{16}$.

\section{Problemy harmonizacji prawa rolnego}

Od czterech lat mamy do czynienia z procesem harmonizacji systemów prawnych polegającym na dostosowaniu nowych regulacji powstałych we Wspólnocie, a także zmianie już obowiązujących regulacji krajowych w związku ze zmieniającym się prawem europejskim. Powstałe dwa poziomy regulacji: krajowy i europejski zobowiązują każdego prawnika do znajomości już nie tylko aktów prawnych wydawanych przez polski parlament, ale także ogromu prawodawstwa wypracowy-

Rolnictwo ekologiczne od producenta do konsumenta, U. Sołtysiak (red.), Warszawa 1995, s. 11-22; U. Sołtysiak, Rolnictwo ekologiczne, (w:) Encyklopedia agrobiznesu, A. Woś (red.), Warszawa 1998, s. 690-694. Ustawa z dnia 30 czerwca 2000 r. Prawo własności przemysłowej (Dz.U. Nr 49, poz. 508 z późn. zm.) zm.); por. T. Twardowski, A. Michalska, Genetycznie modyfikowane organizmy (GMO) a środowisko, Poznań, 1998.

14 M.in. miała temu służyć ustawa z dnia 29 listopada 2000 r. o zbieraniu i wykorzystywaniu danych rachunkowych z gospodarstw rolnych (Dz.U. Nr 3, poz. 20); zintegrowany system zarządzania i kontroli (IACS) składa się z następujących elementów: skomputeryzowanej bazy danych, alfanumerycznego systemu identyfikacji działek rolnych, alfanumerycznego systemu identyfikacji i rejestracji zwierząt oraz zintegrowanego systemu stosowania oraz kontrolowania pomocy. Ustawa z dnia 26 kwietnia 2001 r. o rentach strukturalnych (Dz.U. Nr 52, poz. 539).

M. Gajęcka, Społeczno-ekonomiczne skutki liberalizacji sprzedaży ziemi cudzoziemcom na tle rozwiązań stosowanych w krajach Unii Europejskiej i ich reperkusje społeczne, (w:) Korzyści i koszty członkostwa Polski w Unii Europejskiej, J. Kotyński (red.), Warszawa 2000; A. Lichorowicz, Wpływ postanowień Układu Europejskiego na zasady nabywania przez podmioty z Unii Europejskiej nieruchomości położonych na terytorium Polski, (w:) Prawo rolne. Biała Księga, Warszawa 1995, s. 186-230. 
wanego, w sferze prawa rolnego, od 25 marca 1957 r. ${ }^{17}$ Niezwykłej szczegółowości nabierają przepisy dotyczące prawa żywnościowego. Zapewnienie tak samo wysokiego bezpieczeństwa żywności i produktów żywnościowych w całej Wspólnocie zmusza do wprowadzenia kontroli produkcji żywności według zasady „od pola do stołu"18.

Nowego znaczenia nabierają przekształcenia wewnętrzne prawa krajowego w porównaniu do regulacji Unii Europejskiej ${ }^{19}$. Tworzone prawo uwzględnia istniejące wytyczne i zalecenia wspólnotowe w regulowanym obszarze. Do polskiego systemu prawa wprowadzono wiele regulacji zbliżonych do uregulowań przyjętych w UE lub tożsamych z nimi ${ }^{20}$. Należy zauważyć, że harmonizacja obejmowała wszystkie poziomy prawodawstwa. Zaczynając od ustaw uchwalanych przez parlament, poprzez różnego typu akty wykonawcze, do krajowych ustaw oraz rozporządzeń europejskich, kończąc na - co prawda nielicznych w tym zakresie - aktach prawa miejscowego. Proces harmonizacji prawa polega dziś na przyjmowaniu regulacji europejskich jako własnych regulacji krajowych. Nie dotyczy to materii objętych zakresem działania rozporządzeń europejskich, w odniesieniu do których działa zasada autowykonalności. Niewątpliwe trudności nie tylko techniczne czy finansowe w tym procesie nie sprzyjają pełnej harmonizacji. Polska nie jest jednak wśród państw członkowskich wyjątkiem.

Międzynarodowe regulacje Unii Europejskiej, m.in. Europejski kodeks celny, obowiązują nie tylko kraje członkowskie, ale również oddziaływują na państwa trzecie. W tym zakresie Polska straciła uprawnienia w handlu międzynarodowym. Obowiązująca wszystkie 27 państw jednolita stawka celna, według specjalnego taryfikatora, stała się łatwym narzędziem upraszczającym obrót również produktami rolnymi i żywnościowymi. Oczywiście, towary rolne także z Polski muszą sprostać wysokim standardom jakościowym oraz konkurencyjnym cenom. W tym zakresie rolnictwo polskie, a w szczególności sektor rolno-spożywczy musi sprostać standardom urzędowej kontroli żywności.

Wtedy to sformułowano w Traktacie Rzymskim zasady Wspólnej Polityki Rolnej; por. M. Cieplewska, Wspólna Polityka Rolna EWG, Warszawa 1981, s. 10 i nast.; T. Oppermann. Europarecht, München 1991, s. 481; M. Cieplewska, Polskie rolnictwo a Wspólna Polityka Rolna Unii Europejskiej, (w:) Stowarzyszenie Polski z Unią Europejska. Niezbędne procesy dostosowawcze polskiej gospodarki żywnościowej, Warszawa 1996; P. Czechowski. M. Korzycka-Iwanow, S. Prutis, A. Stelmachowski, Polskie prawo rolne na tle ustawodawstwa Unii Europejskiej, Warszawa 1997; P. Czechowski, K. Marciniuk, E. Przybylska, Polityka wobec rolnictwa i wsi w świetle procesów dostosowujących rolnictwo polskie do warunków Unii Europejskiej - sfera regulacyjna, Warszawa 1995; E. CałaWcinkiewicz, Charakter prawny Unii Europejskiej w świetle prawa międzynarodowego, Warszawa 2007. M. Korzycka-Iwanow: Prawo..., op. cit.; M. Korzycka-Iwanow (red.), Studia z prawa żywnościowego, Warszawa, 2006; P. Wojciechowski, Wspólnotowy..., op. cit.

19 Por. W. Czapliński, P. Czechowski, A. Proksa, Opinia w sprawie harmonizacji prawa polskiego z prawem Unii Europejskiej, „Przegląd Legislacyjny” 2003, nr 1, s. 179-189; J. Barcz, Efektywność prawa wspólnotowego w prawie krajowym w sprawie wytycznych techniki prawodawczej, „Przegląd Legislacyjny” 2003, nr 2, s. 9-28; P. Czechowski, Dostosowanie... op. cit., s. 60 i nast. 


\section{Stosowanie norm prawa europejskiego}

Jednym z problemów dla polskiego systemu prawa odnośnie do harmonizacji prawa jest problem tzw. implementacji miękkiego prawa, czyli standardów europejskich, które są tylko rekomendowane oraz tzw. utartej i sprawdzonej praktyki lub zwyczaju. Jak podkreślano w literaturze, prawo miękkie definiuje się jako: „zasady postępowania", które z mocy prawa nie są obowiązujące, jednakże mogą wywołać pewne skutki praktyczne ${ }^{21}$. To rozróżnienie, nieznane do tej pory polskiemu prawu w hierarchii źródeł polskiego prawa, staje się problematyczne w jego zrozumieniu. Mamy do czynienia z podwójnym systemem regulacji. Pierwszy polega na bezpośrednim stosowaniu norm prawa europejskiego wynikających z rozporządzeń oraz na pełnej harmonizacji aktów prawnych, czyli tzw. harmonizacja twarda. Drugi system to dostosowanie i harmonizacja polskiego prawa w oparciu o dyrektywy, standardy, zasady, zwyczaj prawa europejskiego. Oba te systemy stanowią źródło praw i obowiązków obywateli, w tym rolników. W ostatnim czasie zarysowuje się tendencja do zmian już raz uchwalonych polskich aktów prawnych wraz ze zmianą prawodawstwa europejskiego. W ten sposób proces harmonizacji odbywa się ciągle, gdyż tylko krajowy prawodawca może w kwestiach regulowanych aktami, które nie są bezpośrednio stosowane, doprowadzić do odpowiedniego efektu w postaci porządnej regulacji.

Jak wskazano w literaturze przedmiotu cytowanej powyżej, soft law staje się coraz bardziej użyteczne i służy rozwojowi. Poprzez komunikaty informacyjne, kodeksy postępowania, statuty, wytyczne, schematy czy instrukcje wewnętrzne instytucje wspólnotowe oddziaływują na adresatów prawa. Forma aktu prawnego staje się jak najprostsza zarówno w budowie, jak i w trybie wydawania. Cel regulacji staje na pierwszym miejscu i to cel ma być wyznaczony w danym akcie prawnym, który później będzie stosowany w prawie państw członkowskich. Regulacje pochodzące z wyżej wspomnianych aktów prawnych stają się czasami prawem stanowionym przez państwa członkowskie, stając się jednocześnie prawem powszechnie obowiązującym.

Prawna regulacja unijna, w szczególności pod wpływem wykładni Europejskiego Trybunału Sprawiedliwości, upodabnia się dużo bardziej niż prawo polskie, do prawa anglosaskiego. Prawo, które jest zaleceniem danego postępowania, normy prawne wywodzone i stosowane z orzeczeń sądowych, precedensowe sprawy stawiają przed polskim prawodawcą nowe wyzwania. Konieczność zmiany systemu myślenia o prawie pisanym jako jedynym i właściwym źródle prawa, zaznacza się prawa integracji europejskiej w krajowych porządkach prawnych, C. Mik (red.), Toruń 1998, s. 11-20 i literatura tam przywołana. 
co prawda jeszcze dość niewyraźnie na tle dziesiątek tysięcy szczegółowych regulacji prawnych, ale nabiera coraz większego znaczenia.

Prawo europejskie praktycznie nie funkcjonuje bez orzeczeń sądowych, które nadają mu właściwą treść i dokonują jego interpretacji. To orzeczenia sądowe uczą współczesnego prawodawcę, a jeszcze bardziej współczesnych adresatów norm europejskich, jak należy rozumieć prawo, które jest niejednokrotnie bardzo zawiłe. To właśnie orzeczenia sądowe formułują nowe zasady interpretacyjne prawa, które pod jego wpływem w drodze wykładni stają się prawem stosowanym.

\section{Europeizacja języka prawnego}

Należy również bacznie przyjrzeć się problemom językowym przy harmonizacji i implementacji prawa ${ }^{22}$. To od właściwie zbudowanego języka prawa, czyli języka aktów prawnych, będzie w dużej mierze zależało powodzenie procesów harmonizacji i implementacji. Europeizacja języka polskiego prawa rolnego następuje w błyskawicznym tempie. Od stosowania nowego nazewnictwa, takiego jak np. dopłaty, subwencje, licencje eksportowe, importowe, certyfikaty, produkt pierwszego przetworzenia, kwotowanie, zależy nadawanie nowego znaczenia pojęciom treściowym zastanym w polskim prawie, takim jak gospodarstwo rolne, nieruchomość rolna, rolnik. Wielość nowych znaczeń oraz duża liczba zmian instytucji prawnych już istniejących w polskim prawie nie sprzyja szybkiemu sprostaniu wyzwaniom, jakie stawiają przed polskim rolnictwem regulacje europejskie. Potrzeba jeszcze pewnego okresu czasu, aby nowe pojęcia na stałe weszły do użytku nie tylko prawników, w tym agrarystów, ale również zwykłych adresatów wprowadzanych zmian. Bez tego nie będzie możliwe pełne wykorzystanie wszelkich korzyści, jakie płyną z członkostwa w Unii Europejskiej. Pewne zadanie staje w tym miejscu przed językoznawcami oraz tłumaczami, którzy wspólnie z prawnikami powinni dążyć do jak najbardziej zrozumiałego sformułowania polskich aktów prawnych.

Postępującą europeizację języka prawnego w sektorze prawnorolnym należy ocenić pozytywnie. Zastosowanie jasnych, szczegółowych reguł pozwala na zwiększenie wydajności produkcji, zapewnienie bezpieczeństwa zaopatrzenia, zwiększenie dochodowości rolnictwa. Zastosowanie tych samych nazw, czasem nawet oznaczeń graficznych, jak na produktach żywnościowych, podnosi bezpieczeństwo konsumenta i sprawia, że niezależnie od tego, w którym z 27 państw znajdzie się konsument, może być pewien, że produkty rolne bądź żywnościowe są odpowiednio wysokiej jakości. Europeizacja nazewnictwa i jego rozumienie największy wpływ wywiera na polu importu i eksportu zarówno wewnątrzunijnego, jak i do państw 
trzecich. Jednolite reguły stwarzają równe szanse dla rolników z różnych państw w sferze konkurencji.

Europeizacja języka prawa rolnego ma jednak również i wady. Stosowanie opisywanego jednolitego nazewnictwa może prowadzić niejednokrotnie do nieporozumień. Czasami jego wprowadzenie jest wręcz niemożliwe. Opisywane instytucje w okresie przejściowym napotykają wiele trudności, odnośnie do ich zastosowania i wdrożenia. Wystarczy tu wspomnieć chociażby istniejące nadal problemy z wypłatami dopłat dla rolników, czy też obniżającą się rentą strukturalną.

Nowe tendencje w prawie rolnym po akcesji Polski do Unii Europejskiej budują nowy katalog problemów, przed którymi przychodzi stanąć polskiemu prawodawcy. Przede wszystkim należy zwrócić uwagę, że harmonizacja dyrektyw unijnych ma polegać nie tylko na dosłownym ich przetłumaczeniu i nadaniu im tytułu polskiego aktu prawnego. Dyrektywa zakreśla tylko cele realizacji, wskazuje przykładowe środki do zastosowania, aby osiągnąć cel. To państwo członkowskie ma zdecydować, jak te cele zrealizować i jakimi środkami. Tymczasem implementowanie tłumaczeń dyrektyw niekiedy będzie sprzyjało wręcz hamowaniu zamierzonych procesów. Należy bacznie i od samego początku realizować rolę dyrektyw, które same w sobie nie są źródłem prawa bezpośrednio dotykającym obywateli. Są to tylko wytyczne dla państwa, wytyczne, a nie polecenie bezwzględnego, nawet najbardziej nieracjonalnego stosowania prawa.

\section{Przeciwdziałanie kolizyjności regulacji prawnej}

Kolejny problem stanowi przeciwdziałanie kolizyjności polskiego i unijnego prawa. Pytanie, któremu z tych porządków dać pierwszeństwo, wydaje się być rozwiązane tylko połowicznie. Żaden z wymienionych systemów prawnych nie może sobie rościć pretensji do absolutnego pierwszeństwa w stosowaniu. Pomimo sformułowania w tym zakresie reguł przez Europejski Trybunał Sprawiedliwości, problem powstaje już w przypadku stosowania Konstytucji Rzeczypospolitej Polskiej. Czy jest w polskim systemie prawa akt wyższego rzędu, czy te same zasady mają zastosowanie w prawie europejskim? Właściwe usystematyzowanie dalszego katalogu źródeł obowiązującego w Polsce prawa polskiego i europejskiego ${ }^{23}$, a w szczególności budowa jego hierarchii budzi wiele emocji nie tylko zresztą wśród prawników. Rozwiązania przyjęte w orzecznictwie Trybunału Konstytucyjnego nie dają również pełnej i satysfakcjonującej odpowiedzi na rodzące się pytania ${ }^{24}$. Europejski Trybunał Sprawiedliwości już dawno rozstrzygnął wszelkie wątpliwości w tej kwe- 
stii. Już w 1963 r. w orzeczeniu Van Gend an Loos v. Nederlandse Administratie der Belastingen ${ }^{25}$ postanowiono, że prawo Wspólnoty Europejskiej stanowi odrębny porządek prawny, a taki charakter prawa wspólnotowego nie wyklucza, a nawet zakłada występowanie jego różnorodnych powiązań z prawem państw członkowskich ${ }^{26}$. W kolejnym orzeczeniu, Costa v. Enel ${ }^{27}$, Europejski Trybunał Sprawiedliwości jasno stwierdził, że prawo wspólnotowe ma pierwszeństwo przed prawem państw członkowskich. Żadne przepisy prawa krajowego nie mogą przeważać nad prawem wywodzącym się z Traktatu, będącym niezależnym źródłem prawa ${ }^{28}$. Z problemem tym musi zmierzyć się polskie ustawodawstwo. Należy doprecyzować reguły nowej hierarchii źródeł prawa, aby móc spokojnie odnaleźć w tym gąszczu przepisów prawo europejskie.

Kolejny problem to możliwość wystąpienia kolizji dwóch regulacji: polskiej i unijnej. Coraz więcej obszarów regulowanych jest w drodze rozporządzeń europejskich, które mają klauzulę autowykonalności, wcześniej zaś były transponowane do ustawodawstwa krajowego poprzez kopiowanie regulacji prawnych, tzw. ,metodę kalki”. Problem powstaje wtedy, gdy nowa regulacja europejska obowiązuje już w krajowym obrocie prawnym, dostosowana na podstawie dyrektyw. Powstaje pytanie, jaką rolę pełnią tutaj ustawy? Nowo wydane rozporządzenie dotyczące np. branżowych rynków rolnych z $2007 \mathrm{r}^{29}$ oraz obowiązujący szereg ustaw polskich dla poszczególnych rynków stają się tutaj jaskrawym przykładem. Czy nowe rozporządzenie uchyla obowiązywanie polskich ustaw? Jaki będzie efekt, gdy pomiędzy tymi aktami prawnymi zaistnieje dość istotna różnica, żeby nie powiedzieć sprzeczność, do którego aktu prawnego ma się stosować polski obywatel i producent rolny? W chwili obecnej pytania te znajdują tylko częściowe odpowiedzi.

\section{Uwagi końcowe}

Okres członkostwa Polski w Unii Europejskiej pokazał, że nie sprawdziła się większość obaw towarzyszącym zmianom. Cztery ostatnie lata pokazały, że polskie rolnictwo potrafi być konkurencyjne nie tylko cenowo, ale przede wszystkim jakościowo. Niższe koszty produkcji muszą iść jednak w parze z trudną do pogo-

Por. S. Biernat, Prawo Unii Europejskiej a prawo państw członkowskich, (w:) Prawo Unii Europejskiej, J. Barcz (red.), Warszawa 2003, s. 233 i nast.

Zb. Orz. 1964, orzeczenie 16/64.

Por. orzeczenie 11/70 Internationale Handelsgesellschaft v. Einfuhr- und Vorratstelle für Getreide und Futtermittel, Zb. Orz. 1970, s. 1125; orzeczenie 106/77 Amministrazione delle Finanze dello Stato v. Simmenthal, Zb. Orz. 1978, s. 629; orzeczenie C-224/97 Ciola v. Land Vorarlberg, Zb. Orz. 1999, s. I-2517; orzeczenie C-10-22/97 Ministero delle Finanze v. IN. CO. GE. ' 90 Srl, Zb. Orz. 1998, s. I-6307; orzeczenie C-11/92 The Queen v. Secretary for Heath, ex parte Gallaher Ltd and others, Zb. Orz. 1993, s. I-3545; orzeczenie 103/88 Fratelli Costanzo v. Commune di Milano, Zb. Orz. 1989, s. 1839; orzeczenie C-118/00 Larsy v. Inasti, Zb. Orz. 2002, s. I-5063; orzeczenie 167/73 Commission v. France, Zb. Orz. 1974, s. 359.

Rozporządzenie UE nr 1234/2007 z 22 października 2007 r. ustanawiające wspólną organizację rynków rolnych Rozporządzenie Rady (WE) nr 1234/2007 z dnia 22 października $2007 \mathrm{r}$.

(1)


dzenia potrzebą restrukturyzacji i modernizacji. Wykorzystywanie w tym zakresie środków, w szczególności pochodzących z tzw. II filara Wspólnej Polityki Rolnej, musi być efektywniejsze.

Projektowana jest m.in. również zmiana ustawy o kształtowaniu ustroju rolnego, zmniejszająca obszar powierzchni gospodarstwa rodzinnego z 300 ha do 100 ha. ${ }^{30}$ Wyżej wymienione zmiany, podyktowane problemami doktrynalnymi, nie uwzględniają konieczności odniesienia się do systemu finansowania rolnictwa z Unii Europejskiej (dotacje) dotyczącego maszyn rolniczych. Z badań przeprowadzonych przez Instytut Budownictwa, Mechanizacji i Elektryfikacji Rolnictwa ${ }^{31}$ wynika, że efektywność ekonomiczna niektórych maszyn rolniczych, m.in. kombajnów, rozpoczyna się od progu 100 ha powierzchni gruntów rolnych. Przestrzec należy zatem przed mechanicznym ograniczaniem powierzchni norm obszarowych, gdyż ekonomika rolnictwa wskazuje na konieczność utrzymywania większych areałów i rozłogów pól w związku z wprowadzaniem nowych maszyn rolniczych, których zakup przez rolników może być wspomagany ze środków UE.

Należy również zwrócić uwagę na zmieniającą się wielkość obszarową gospodarstw w krajach europejskich, a co za tym idzie - zmianę struktur agrarnej (por. załącznik nr 1 i nr 2).

Wiele nowych wyzwań staje przed właściwym promowaniem polskiej żywności i produktów rolnych ${ }^{32}$. To skuteczny marketing, a nie tylko prawo w dużej mierze przesądzą o sukcesie bądź porażce polskiego sektora rolnego. Obecnie polskie firmy konkurują na rynku europejskim jakością i bezpieczeństwem żywności dostosowanym do wymagań odbiorców. Polskie firmy muszą nawiązać kontakty z sieciami handlowymi o globalnym zasięgu, aby móc zdobywać nowe rynki również poprzez konkurencję ilościową, zachowując obecny wysoki poziom jakości. Sektor żywności już obecnie musi zmierzyć się m.in. z problemem żywności modyfikowanej genetycznie czy też problemem tzw. „fałszowania” żywności. Odpowiednie regulacje prawne nie tylko europejskie, ale przede wszystkim krajowe powinny zawczasu stworzyć odpowiednie ramy prawne, zapewniające wysoki poziom bezpieczeństwa.

30 Poselski projekt ustawy o zmianie ustawy o kształtowaniu ustroju rolnego oraz o zmianie niektórych innych ustaw (druk nr 687 wpłynał 30-11-2007; z opisu: projekt dotyczy m.in. zakresu przedmiotowego prawa pierwokupu przysługującego dzierżawcy nieruchomości rolnej, definicji "gospodarstwa rodzinnego", definicji "rolnika indywidualnego", katalogu dowodów potwierdzających posiadanie kwalifikacji rolniczych. Projekt zmierza również do modyfikacji zakresu zadań Agencji Nieruchomości Rolnych, opłaty związanej ze zbyciem prawa użytkowania wieczystego nieruchomości rolnej, zasad gospodarki finansowej Agencji Nieruchomości Rolnych i Zasobu Własności Rolnej Skarbu Państwa oraz zasad gospodarowania Zasobem Własności Rolnej Skarbu Państwa. co-wydzielające i czyszczące w kombajnach do zbioru zbóż, Warszawa 2000; T. Karwowski, Podstawy zespołowego użytkowania maszyn w aspekcie efektywności produkcji roślinnej, Warszawa 2008. 
Kolejnym wyzwaniem staje się potrzeba wprowadzenia nie tylko do produkcji spożywczej, ale przede wszystkim rolnej innowacyjnych technologii. W tym zakresie polscy rolnicy nie poradzą sobie bez odpowiedniego prawa polskiego i możliwości pozyskiwania dotacji z funduszy europejskich. Najbliższe lata należy poświęcić na wdrażanie nowoczesnych systemów zarządzania, działalność wdrożeniowo-innowacyjną, budowanie marki, nowe kanały dystrybucji, reklamę i marketing ${ }^{33}$

Wraz z końcem tzw. okresów przejściowych zakończy się okres „ochronny” dla polskiego rolnictwa i przetwórstwa rolno-spożywczego. Polscy rolnicy muszą sprostać konkurencji bez specjalnych środków pomocowych, czy bez możliwości skorzystania z obniżenia niektórych standardów, np. w warunkach sanitarno-technologicznych. Wystarczy tu wspomnieć tak mitologizowane zakończenie okresów przejściowych dotyczące nabywania nieruchomości przez cudzoziemców. Przed polskim prawodawcą staje nowe wyzwanie sprostaniu rodzącej się nowej sytuacji prawnej. Jak zachowując wszelkie reguły europejskiej wolnej konkurencji i wolnego rynku pomóc polskim rolnikom. Należy już dziś pomyśleć, jak pomóc tym, którzy pozbawieni możliwości jakie dawały okresy przejściowe, nie poradzą sobie w nowej sytuacji społeczno-ekonomicznej.

Wysoka specjalizacja regulacji prawnych z jednej strony sprzyja podnoszeniu bezpieczeństwa jakości produktów rolnych i żywnościowych czy właściwej hodowli zwierząt. $Z$ drugiej jednak taka segmentacja sytemu prawa i jego ubranżowienie przyczyniają się do destabilizacji prawa. Często w tych segmentach spotykamy regulacje zupełnie ze sobą sprzeczne. Prawodawca czy to krajowy, czy europejski musi mieć na uwadze cały system prawa, a nie tylko wąsko wyspecjalizowaną jedną gałąż́z ${ }^{4}$. Dopiero zapewnienie spójnej regulacji może przyczynić się do właściwego rozwoju.

Jakie są perspektywy metod regulacji w prawodawstwie prawnorolnym? Niewątpliwe metoda administracyjnoprawna nadal będzie odgrywała dużą rolę. Nie ma dziś możliwości, aby zaniechać w ciągu najbliższych lat przyznawania kwot produkcyjnych, koncesjonowania produkcji, wypłacania dopłat, czy odstąpić od urzędowej kontroli bezpieczeństwa żywności. Rolnictwo w tym zakresie wymagało i będzie wymagać ingerencji państwa. Bez nadzoru państwa nad systemem rozdziału dopłat i funduszy pomocowych wielu rolników musiałoby zlikwidować swoje gospodarstwa. Dotyczy to również administrowania eksportem i importem produktów rolnych ${ }^{35}$.

S. Zięba, Sektor rolno-żywnościowy, jakie perspektywy w poszerzonej Unii Europejskiej?, (w:) Rolnictwo i przemysł spożywczy cztery lata po rozszerzeniu Unii Europejskiej - czy wykorzystaliśmy szansę?, Warszawa 2008, s. 4-5. Rolna, „Przegląd Prawa Rolnego” 2007, nr 2, s. 125-150. 
Tendencje rozwoju polskiego prawa rolnego w związku z uzyskaniem członkostwa Polski...

Prawo rolne będzie skoncentrowane w dużej mierze na problematyce interwencji państwa, wykorzystując metody prawnoadministracyjne, jak również czynnik prywatny, w zakresie programu rozwoju obszarów wiejskich i infrastruktury techniczno-społecznej. Program rozwoju obszarów wiejskich zakłada wiele zmian w kolejnych okresach (najbliższy w latach 2007-2013) ${ }^{36}$, które mogą być zaplanowane spójnie w skali całego kraju tylko przez władzę publiczną. Właściwe regulacje, które są wprowadzane i które należy jeszcze wprowadzić, będą miały na celu maksymalne wykorzystanie środków finansowych, dzięki którym ma zmienić się obraz polskiej wsi. Prawo rolne intensywnie będzie nadal wspomagać powyższy proces.

Załącznik nr 1. Zmiany powierzchni gospodarstw rolnych w krajach UE ${ }^{37}$

\begin{tabular}{|c|c|c|c|c|c|}
\hline \multirow{2}{*}{ Kraje } & \multicolumn{4}{|c|}{$\begin{array}{l}\text { Powierzchnia gospodarstwa i jej zmiany } \\
\text { (ha UR) }\end{array}$} & \multirow{2}{*}{$\begin{array}{l}\text { Obsada siły roboczej } \\
\text { (pełnozatrudnieni na } \\
100 \text { ha UR w } 2002 \text { r.) }\end{array}$} \\
\hline & 1975 & 1995 & 2003 & $\begin{array}{l}\text { Wskaźnik zmian } \\
\quad(1975=100)\end{array}$ & \\
\hline Belgia & 10,6 & 18,8 & 25,9 & 244 & 5,3 \\
\hline Dania & 22,4 & 37,1 & 55,1 & 246 & 2,5 \\
\hline Francja & 22,4 & 38,5 & 45,8 & 204 & 3,4 \\
\hline Holandia & 12,8 & 17,7 & 23,8 & 186 & 10,1 \\
\hline Irlandia & 22,3 & 28,2 & 32,3 & 145 & 3,8 \\
\hline Luksemburg & 22,0 & 39,5 & 52,8 & 240 & 3,5 \\
\hline Niemcy & 13,7 & 30,3 & 41,3 & 301 & 3,6 \\
\hline
\end{tabular}

Program Rozwoju Obszarów Wiejskich na lata 2007-2013; por. przykładowe akty prawne wydane w ramach PROW: Rozporządzenie Ministra Rolnictwa i Rozwoju Wsi z dnia 14 marca 2008 r. w sprawie szczegółowych warunków i trybu przyznawania oraz wypłaty pomocy technicznej w ramach Programu Rozwoju Obszarów Wiejskich na lata 2007-2013 (Dz.U. Nr 54, poz. 329); Rozporządzenie Ministra Rolnictwa i Rozwoju Wsi z dnia 27 lutego 2008 r. w sprawie podziału środków Programu Rozwoju Obszarów Wiejskich na lata 2007-2013 (Dz.U. Nr 34 poz. 199); Rozporządzenie Ministra Finansów z dnia 25 października 2007 r. zmieniające rozporządzenie w sprawie przyznania Agencji Restrukturyzacji i Modernizacji Rolnictwa tymczasowej akredytacji jako agencji płatniczej, w zakresie uruchamiania środków pochodzących z Europejskiego Funduszu Rolniczego Gwarancji oraz Europejskiego Funduszu Rolniczego Rozwoju Obszarów Wiejskich (Dz.U. Nr 201, poz. 1451); Rozporzadzenie Ministra Rolnictwa i Rozwoju Wsi z dnia 19 października 2007 r. w sprawie podziału środków Programu Rozwoju Obszarów Wiejskich na lata 2007-2013 (Dz.U. Nr 201, poz. 1460); Rozporządzenie Ministra Rolnictwa i Rozwoju Wsi z dnia 6 sierpnia 2007 r. w sprawie szczegółowego zakresu zadań instytucji zarządzającej wykonywanych przez niektóre podmioty jako zadania delegowane oraz sposobu ich wykonywania w ramach Programu Rozwoju Obszarów Wiejskich na lata 2007-2013 (Dz.U. Nr 150, poz. 1067); Ustawa z dnia 7 marca 2007 r. o wspieraniu rozwoju obszarów wiejskich z udziałem środków Europejskiego Funduszu Rolnego na rzecz Rozwoju Obszarów Wiejskich (Dz.U. Nr 64, poz. 427); Rozporządzenie Ministra Finansów z dnia 16 października 2007 r. w sprawie przyznania Agencji Restrukturyzacji i Modernizacji Rolnictwa tymczasowej akredytacji jako agencji płatniczej, w zakresie uruchamiania środków pochodzących z Europejskiego Funduszu Rolniczego Gwarancji oraz Europejskiego Funduszu Rolniczego Rozwoju Obszarów Wiejskich (Dz.U. Nr 193, poz. 1396); Rozporządzenie Ministra Rolnictwa i Rozwoju Wsi z dnia 31 sierpnia 2007 r. w sprawie szczegółowego sposobu sprawowania nadzoru nad podmiotami, które wykonuja jako delegowane zadania instytucji zarządzającej w ramach Programu Rozwoju Obszarów Wiejskich na lata 2007-2013 (Dz.U. Nr 163, poz. 1160).

37 Źródło: W. Ziętara, Dzierżawa jako czynnik przemian w strukturze gospodarstw, ZN SGGW 2006, nr 58. 
Paweł Czechowski, Adam Niewiadomski

\begin{tabular}{|l|c|c|c|c|c|}
\hline Wielka Brytania & 58,7 & 70,1 & 65,8 & 112 & 2,1 \\
\hline Włochy & 6,2 & 5,9 & 6,7 & 108 & 10,4 \\
\hline Polska & 5,5 & 7,0 & 8,7 & 158 & 12,5 \\
\hline
\end{tabular}

Załącznik nr 2. Gospodarstwa rolne według form własności i grup obszarowych użytków rolnych ${ }^{38}$

\begin{tabular}{|c|c|c|c|c|}
\hline \multirow{2}{*}{ Wyszczególnienie } & \multicolumn{2}{|c|}{ Gospodarstwa } & \multicolumn{2}{|c|}{$\begin{array}{l}\text { Powierzchnia użytków } \\
\text { rolnych }\end{array}$} \\
\hline & $\begin{array}{c}\text { w liczbach } \\
\text { bezwzględnych }\end{array}$ & W odsetkach & w hektarach & w odsetkach \\
\hline O g ółe m & 2579178 & 100,0 & 16177081 & 100,0 \\
\hline Sektor prywatny & 2578163 & 100,0 & 15607524 & 96,5 \\
\hline w tym: & & & & \\
\hline $\begin{array}{l}\text { Gospodarstwa indywidualne } \\
\text { w grupach obszarowych } \\
\text { użytków rolnych: }\end{array}$ & 2575113 & 99,8 & 14418199 & 89,1 \\
\hline $0-1$ ha & 771050 & 29,9 & 330824 & 2,0 \\
\hline $1-2$ & 422533 & 16,4 & 613315 & 3,8 \\
\hline $2-3$ & 273675 & 10,6 & 667412 & 4,1 \\
\hline $3-5$ & 340303 & 13,2 & 1322528 & 8,2 \\
\hline $5-10$ & 399868 & 15,5 & 2836174 & 17,5 \\
\hline $10-15$ & 166435 & 6,5 & 2019873 & 12,5 \\
\hline $15-20$ & 77474 & 3,0 & 1333099 & 8,2 \\
\hline $20-30$ & 65189 & 2,5 & 1568085 & 9,7 \\
\hline $30-50$ & 37126 & 1,4 & 1387460 & 8,6 \\
\hline $50-100$ & 15615 & 0,6 & 1044238 & 6,5 \\
\hline
\end{tabular}

Źródło: Charakterystyka gospodarstw rolnych, GUS, Warszawa 2008, s. 154. 
Tendencje rozwoju polskiego prawa rolnego w związku z uzyskaniem członkostwa Polski...

\begin{tabular}{|c|c|c|c|c|}
\hline $100-200$ & 3883 & 0,2 & 520213 & 3,2 \\
\hline $200-300$ & 976 & 0,0 & 236854 & 1,5 \\
\hline $300-500$ & 608 & 0,0 & 228604 & 1,4 \\
\hline $500-1000$ & 311 & 0,0 & 208943 & 1,3 \\
\hline 1000 ha i więcej & 68 & 0,0 & 100577 & 0,6 \\
\hline Sektor publiczny & 1015 & 0,0 & 569557 & 3,5 \\
\hline
\end{tabular}




\section{Development tendencies of Polish agricultural law in relation with Polish association with the European Union}

\section{Summary}

Polish accession to the European Union along with ten other states on 1 May 2004 caused significant changes in the field of law in all its aspects. The process of harmonization of Polish law with European law was complicated, although quick. Proper execution of European law standards was given special significance. We are observing Europeization of the legal language. Court statements, above all of the European Tribunal of Justice, are to prevent collisions of the individual standards. The growth of significance of proper interpretation of law is very important.

Poland's membership period in the European Union showed that most concerns accompanying change had not came true. Regulations regarding the agricultural system are acquiring shape. Proper promotion of Polish food and agricultural products face many new challenges. The need to introduce innovative technologies not only to food production processes, but also to agricultural production becomes a challenge. Along with expiration of the so-called transitional periods the "protective" period for Polish agriculture and agricultural-food processing industry will come to an end. Polish farmers will have to meet all the European requirements. 